\title{
BOWLBY BEFORE BOWLBY: THE SOURCES OF AN INTELLECTUAL DEPARTURE IN PSYCHOANALYSIS AND PSYCHOLOGY
}

\author{
SUZAN VAN DIJKEN, RENÉ VAN DER VEER, MARINUS VAN IJZENDOORN, AND HANS-JAN KUIPERS
}

\begin{abstract}
John Bowlby's first scientific papers express a viewpoint of the etiology of childhood disorders that gradually developed during his university years and the first years of his professional life. As becomes clear from, among other things, Bowlby's private correspondence, it was the period spent as a student at Cambridge, his work as a teacher at two progressive schools, and his work at a child guidance clinic that allowed him to articulate a view on childhood deviancy that was at variance with the Kleinian variant of psychoanalysis. Bowlby's position as an 'independent' thinker in the British Psycho-Analytical Society can be understood against the background of these intellectual influences. (C) 1998 John Wiley \& Sons, Inc.
\end{abstract}

John Bowlby (1907-1990), the founder (together with Mary Ainsworth) of attachment theory, published his first popular and scientific papers when he was in his early thirties. ${ }^{1}$ In these papers, he advanced a view of the etiology of childhood disorders that was on several points at variance with the psychoanalytic tradition in which he had been reared. From the outset, then, Bowlby presented himself as an independent thinker who accepted certain psychoanalytic views but rejected others. Historians of attachment theory have presented interesting analyses of Bowlby's first scientific articles and books and have rightly argued that they contained the germs of the new attachment paradigm. ${ }^{2}$

In this paper we attempt to supplement their findings and to examine Bowlby's path towards his own independent theoretical view. We shall show that Bowlby's first scientific papers were as much the beginning of a new paradigm as they were the (temporary) end product of his previous intellectual development. Bowlby's early viewpoints on the origins of childhood deviancy gradually took shape and became strenghtened while he studied at Cambridge, worked at various progressive schools, and interacted with numerous colleagues at various institutes. The present paper forms a first and still incomplete attempt to reconstruct this little known but significant period in Bowlby's intellectual development and thus to sketch "Bowlby before Bowlby," that is, before he published his first scientific publications and challenged the accepted views. ${ }^{3}$

In tracing the intellectual roots of Bowlby's thinking and the influences that affected him, we do not for one moment wish to suggest that he was but the product of these various influences. On the contrary, we believe that Bowlby actively sought the experiences and teachings that suited his temperament and desire for knowledge. It was Bowlby who decided

SUZAN VAN DIJKEN wrote her doctoral dissertation at Leiden University which will be published as "John Bowlby: His early life" (London: Free Association Books).

RENÉ VAN DER VEER is associate professor of education at Leiden University. He is interested in the history and theory of developmental psychology.

MARINUS H. VAN IJZENDOORN is professor of Education at Leiden University. He published widely on attachment theory and moral development.

HANS-JAN KUIPERS is working as an educationalist at Leiden University and the Amsterdam Polytechnic. His fields of interest are intellectual history and lifecourse-research.

CORRESPONDENCE ADDRESS: Center for Child and Family Studies, Dept. of Education, University of Leiden, P.O. Box g555, 2300 RB Leiden, the Netherlands. 
to spend a year at Bedales and Priory Gate (see below), it was Bowlby who opted to write a $\mathrm{Ph} . \mathrm{D}$. thesis under Sir Cyril Burt and so on and so forth. By combining and synthesizing the various viewpoints that he accepted, Bowlby gradually developed his own ideas about the origin of maladjustment, a view that later would be enriched by Ainsworth's contribution and grow into the new paradigm of attachment.

The findings presented in this paper are partly based upon a number of interviews conducted with various members of the Bowlby family and with experts on attachment theory; partly upon a study of archival materials; and partly upon a study of the existing scientific literature. Many of the archival materials can be found in the Wellcome Institute and the Tavistock Institute in London. These include Bowlby's private correspondence (of which we make abundant use in this paper), notes, drafts, reviews of his publications, etc. Much of this unique material has only recently become available for study. ${ }^{4}$

\section{The YeARs AT CAMBRIDGE}

Bowlby probably first became acquainted with psychoanalysis during his years as a medical student at Trinity College in Cambridge. When he arrived there in 1925, interest in psychoanalytic ideas was still growing. Indeed, it was difficult not to be confronted with psychoanalytic theory. The popular press in Britain paid much and increasing attention to psychoanalysis, also because it had been widely used to treat the cases of battle neurosis during and after World War I. ${ }^{5}$ But interest in psychoanalytic theory was not restricted to the lay public. Most students of psychology were actively interested in Freudian psychology, as were many of their professors. Even though Freud's views were often met with criticism, it was now generally acknowledged that his views could not be ignored. The whole general atmosphere was aptly described by the New Statesman in 1923: "We are all psychoanalysts now. That is to say that it is as difficult for an educated person to neglect the theories of Freud and his rivals as it would have been for his father to ignore the equally disconcerting discoveries of Darwin."

At Cambridge, Bowlby opted for a course leading to an honors degree, a Tripos. A Tripos was divided into two parts, so that a candidate might take half of one Tripos and half of another. Bowlby began his study with the Natural Sciences Tripos, which was intended for the more ambitious students, as it gave exemption from Part I and II of the Bachelor of Medicine (M.B.) examinations. Biology was a major element in the Natural Sciences Tripos, and many years later Bowlby remembered that he did a considerable amount of work in evolutionary biology. Bowlby's tutor in the natural sciences was Edgar D. Adrian (18891977), who worked in the physiological laboratory of the Faculty of Medicine of Trinity College. If Bowlby had more than a superficial interest in psychoanalytic teaching at this time, Adrian certainly would not have been the person to discourage it. Himself a fine experimenter who made important discoveries in the field of nerve conduction, he displayed an interest in Freudian theory almost from its inception. In his view, psychoanalysis "went far beyond a single range of facts; it showed or tried to show quite unexpected relations between different fields." 7

In June 1927, almost two years after his admission, Bowlby passed the Natural Sciences Tripos Part I. This involved an examination that lasted for three weeks and consisted of a written and an oral, or practical part. The examination was conducted over a wide variety of subjects, such as anatomy, botany, zoology, and mineralogy. To his own great surprise, Bowlby gained first class honors in this examination. As a result, he received a so-called Exhibition, a sum of money to pay for the costs of the study. ${ }^{8}$ This unexpected sum of money 
allowed Bowlby to make a gesture that we can now interpret as the first documented sign of his interest in psychoanalysis: he purchased a copy of W. H. R. Rivers' book Instinct and the Unconscious. Rivers (1864-1922) was not just known - together with A. C. Haddon, Charles S. Myers, and William McDougall - as a participant in the famous British anthropological expedition to Torres Straits (New Guinea), he was also the first president of the Medical Section of the British Psychological Society and an associate member of the British PsychoAnalytical Society. Rivers' book, published in 1920, was highly regarded in contemporary medical circles. Reviewers praised his balanced approach towards psychoanalysis, and they claimed that he lacked the dogmatism and unscientific immoderacy of the Freudians. One feature that appealed to the reviewers was that Rivers de-emphasized the dynamic role of the sexual instinct, particularly in the case of battle neurosis. Bowlby may well have read Rivers' book in Germany, because immediately after his examination, he left for Hagen in Germany to learn German. The German family with whom he stayed made desperate efforts to teach him the language, but Bowlby complained to his mother that "my tongue finds it very hard pronouncing their words." Bowlby's later wife, Ursula, confirmed this account and claimed that he never succeeded in learning German. ${ }^{9}$

Although information about Bowlby's first two years at Cambridge is scarce, we may in summarizing arrive at the following reasonably plausible picture of Bowlby's interests and training during this period. There is little doubt that Bowlby, like many of his contemporaries, took an active interest in the psychoanalytic teachings of the day. The fact that he read Rivers' book demonstrates this, and the fact that he made vain attempts to master the German language can be tentatively interpreted (despite the lack of positive evidence) in the same context. The psychoanalytic teaching with which he was confronted was of the moderate type in which the role of the sexual factor was toned down. His tutor, Adrian, from whom Bowlby claimed to have gained much, combined a vivid interest in psychoanalysis with an emphasis on rigorous experimentation. ${ }^{10}$ Rivers' book represents a similar combination of a critical interest in psychoanalysis with an anthropologist's eye for empirical detail.

It was during his first two years at Cambridge that Bowlby became interested in what would now be called developmental psychology. This led him in his third year at Cambridge to switch to the Moral Sciences Tripos, which consisted largely of philosophy and psychology. One of his principal teachers was Frederic Bartlett (1886-1969), whose lectures Bowlby had attended before as Bartlett was also giving some biology classes in the Natural Sciences Tripos. At the time, Bartlett advocated a matter-of-fact approach to psychology that emphasized the role of observation and experiment without neglecting the potentially valuable information gained by introspection. Perhaps most characteristic of Bartlett was that he managed to do his careful observations and experiments in settings that were as close to real-life situations as scientific rigor permitted..$^{11}$

Judging by what he told his wife about this period, Bowlby was somewhat dissatisfied with what he learned in this year of psychological study. Apparently, he took no interest in "learning about IQ and animals in cages" and would have liked to learn more about the psychoanalytic view of child development. The fact that in this year Bowlby read Freud's Introductory Lectures on Psycho-Analysis (1917), a book that he afterwards would rank among the 11 most important books that he ever read, confirms this supposition. ${ }^{12}$ And yet it can be argued that Bowlby gained valuable psychological skills and knowledge during this whole three-year period. His two principal teachers, Adrian and Bartlett, both displayed an open-minded if not eclectic attitude towards new psychological currents such as psychoanalysis but were no fanatic adherents of any current. Thus, Bowlby was taught neither to believe in extreme behaviorism nor to adhere to dogmatic Freudian theory. If anything, the Cambridge 
variant of psychology was that of careful observation and experimentation in real-life settings. ${ }^{13}$

\section{BedAles AND PRIORY GATE}

Although Bowlby was dissatisfied with his psychological training at Cambridge, he had not lost his interest in developmental psychology. After graduating in 1928, he declined an offer to work as a science teacher at St. Paul's boys' school in London. ${ }^{14}$ Rather, he preferred to broaden his horizon in the field of developmental psychology and education. As he remembered half a century later, "I was really casting around to find out what was available and where, in my field of interest." 15 As a result, Bowlby spent a year working at two progressive schools, first at Bedales and subsequently at Priory Gate. Both schools belonged to the movement of "new education" that flourished in the first decades of this century. Among the catchwords of this movement were such terms as "activity," "freedom," and "selfexpression." 16 According to John Adams' contemporary account, most progressive schools in that period had a practical turn and worked to bring the pupil's school work into more direct relation with what was going on in the out-of-school world. ${ }^{17}$ Educators tried to win children's interest, by letting them develop their natural potentials, and letting them experiment independently with the materials of nature - a continuation of the "back to nature" movement that, before 1924, was most obviously represented by the followers of J. H. Pestalozzi and F. Froebel. ${ }^{18}$

In September 1928, Bowlby began working at Dunhurst, the junior school of Bedales. Bedales, located in Petersfield on the Hampshire Downs, had been founded by John H. Badley in 1893. Badley, who had previously worked with Reddie at the pioneering new school, Abbotsholme, considered "the educational programme of the public schools, with their bias towards the classics, their muscular Christianity and obsession with team games too narrow" and advocated "learning by doing." In his view "experience" should be the universal teacher, a view that he somehow combined with a strong belief in G. Stanley Hall's version of recapitulation theory. In practice, the curriculum was a mixture of conventional teaching and the do-it-yourself laboratory method. ${ }^{19}$

Dunhurst was a coeducational school (which was at the time still highly unconventional) modelled on Montessori principles with the help and approval of Maria Montessori herself. In Badley's view, the main purpose of Dunhurst was the provision of the environment which fostered the child's growth so that the child could "lead a strenuous, eager life, using his faculties to the full." 20

Bowlby began his work at Dunhurst in September 1928 by cleaning up and arranging the science laboratory and the pottery. In November of the same year, he started with physics and chemistry classes in the laboratory. During these classes he attempted to avoid formal teaching and had the children experiment themselves. To this end, he tried to invent "foolproof" experiments the results of which could be understood by the children. Biology he taught in another way, as he could not think of anything to experiment on that might be interesting to the children. He therefore composed simple lectures starting with what he thought the children were primarily interested in, namely their own bodies. Bowlby also introduced the young boys (five to seven years old) to gardening, a task that he feared somewhat "as of course I know nothing whatever about it." Finally, on Saturdays and Sundays he took the largest boys for long and tiring walks in the vicinity. ${ }^{21}$

Bowlby functioned quite well at Dunhurst. Mrs. Fish, the headmistress, was apt to keep him because she thought he got along quite well with the young children. For budgetary 
reasons, however, Bowlby was offered no more than the post of running games and filling gaps at a nominal salary. Understandably, his ambitions went farther than "just to fill in time acting as a general filler-in of gaps." And yet the short period spent at Dunhurst proved fruitful for Bowlby. He realized that he still knew very little of developmental psychology and education and that it was worthwhile to deepen his knowledge in this area. As he formulated it himself, "It is impossible to estimate the scope \& value of work in education, work which has been touched on by most geniuses, $\&$ has been taken for granted by all fools." 22

Bowlby now decided to find another progressive school which would be more suited to his abilities and interests. Among the schools he visited was Neill's Summerhill, which attracted him because of Neill's idea that the child was essentially good and possibly because of its psychoanalytic orientation..$^{23}$ In general, one can say that the more Bowlby saw of these progressive schools, the more he liked them and the more he came to resent the old system of teaching used in traditional schools. As he claimed, "the old repressive schoolmaster awarding prizes, pumping in knowledge, \& dealing out punishments would never suit me." He finally ended up at Priory Gate School in Norfolk, a school even more liberal than Bedales. The decision to opt for this school was made easy by a conversation he had with one of Priory Gate's staff members, John Alford, during his first visit to the school. "When I first visited this place, I had a very long talk with him far into the night and I decided that he knew more about what was of interest to me than anyone I had met so far. And to cut a long story short, I went there." 24

Priory Gate was founded by Theodore James Faithfull in 1919 after he had become increasingly dissatisfied with the education of his own children in the local schools. It was a small residential institution that served about twenty "difficult" or "maladjusted" children of both sexes in the age range of three to eightteen years old. Priory Gate accepted children who "had refused to endure the regime of the ordinary school" and whose behavioral problems (such as nervousness or delinquency) allegedly could be traced to "the over attention of a powerful extraverted [sic] father or mother."25

Faithfull took his educational inspiration from a curious mixture of contemporary theories and world views. Firstly, he strongly believed in the value of the so-called Order of Woodcraft Chivalry (OWC). This was a coeducational, non-religious middle-class movement created by the Quaker Ernest Westlake and his son, Aubrey Westlake, because of their dissatisfaction with the scouting movement. In their view, the scouting movement had lost something of its idealistic character because of the War: "if we are to avoid a repetition of the present awful European disaster [World War I], if we are to make any progress towards a better social and international life, if the 'most great peace' is to become a reality, education must seek to foster and develop all those facilities, instincts and inclinations, which find their highest expression in service." Members of the OWC were taught that 'woodcraft' meant doing and 'chivalry' meant serving. Westlake himself declared that the object of his order was "to put an end to the conflict between instinct and occupation which ever since industrialism began has been the chief cause of man's sorrows and the great obstacle to his progress. ${ }^{26} \mathrm{He}$ too was a firm believer in G. Stanley Hall's recapitulation theory, which held that the cultural history of humankind is repeated in the physical and mental development of children, as "a man cannot grasp the full meaning and significance of civilization unless he himself passed through the stages which have led up to its present form." The educational implications of this view seemed to be that children should be left to run wild (the "great teacher and educator is Nature") to re-discover and re-live the allegedly historical stages of humankind. ${ }^{27}$

The OWC movement with its emphasis on recapitulation theory strongly impressed 
Faithfull and in 1923 he decided to link up Priory Gate with the OWC which meant that all members of the staff and all students were enrolled as members of the OWC. ${ }^{28}$ The activities at Priory Gate clearly revealed the OWC's influence: Lessons took place indoors from September to May, but during the summer months the children and teachers camped in the school grounds, at the seaside, or in the New Forest and made walking and cycling tours to learn from nature. Faithfull combined his strong belief in the OWC movement with an equally strong interest in Freudian theory. Freudian ideas were applied freely in the progressive European schools of the 1920s and different books explained how to do this sensibly. ${ }^{29}$ Psychoanalysis was on the agenda of the 1921 Conference of the Educational Association and Adams, in his book on new developments in education, declared that "the modern teacher who is acquainted with this subject is in a better position to study his pupils with advantage than was his forerunner of the pre-psycho-analytical times." 30

The general ethos of Priory Gate was that the child should be left freely to explore his or her abilities in a setting that provided basic security. ${ }^{31}$ Bowlby himself described this fundamental philosophy in the following words: "the impulses children have are right \& should be allowed to find expression. . . any interference whatever on the part of the adult is dangerous. Except in a few odd cases where a child is prevented from inadvertently committing suicide this principle holds. You may not produce 'good' children, but you will allow Nature to develop complete men and women, instead of the average mental, moral \& physical mediocrities of today." $32 \mathrm{He}$ believed that the only underlying teaching principle at Priory Gate was to give the children material on which they could use their minds and, he therefore tried to discover subjects that would appeal to them. Bowlby, who worked at Priory Gate for a nominal salary and his board and lodging, was asked to try his skills in the so-called Woodling group, a group of about ten children in the age range of eight to twelve. It was very much up to him to decide what to do with this group, and he chose to teach elementary science, physical geography, writing, and history. Other teachers added craftwork, printing, carpentry and similar subjects. By all accounts, Bowlby seems to have been quite successful as a teacher. The children generally liked him, and he got along particularly well with the most "difficult" children. ${ }^{33}$

Two children at Priory Gate had a great impact on Bowlby's thinking. One was a small boy of seven, who was known as Bowlby's 'shadow' because he spent his whole day following him. The other was a boy of sixteen who was very isolated and emotionally shut in. The boy was in the habit of pilfering, for which he was expelled from Eton. It turned out that the boy was an illegitimate child of well-to-do parents and had been brought up by a trained nurse. His emotional problems began when the nurse left, and at Priory Gate it was believed that her departure caused the child's condition. ${ }^{34}$ This implies that the version of psychoanalysis favored at Priory Gate gave due emphasis to real-life events. Faithfull thought that present problems of children stemmed from adverse experiences in their families in the past. He expressed this idea as follows: "The attachment of a child is a normal instinct, but it becomes a danger if it is used for the satisfaction of the adult and not the protection of the child. . . This may show itself in physical collapse or stealing, lying." 35 This basic idea "struck a cord" in Bowlby, and many years later he would positively declare, "So the idea that certain sorts of experience in early childhood have that kind of effect on character and development was picked up there." 36

One of the persons who was instrumental in shaping Bowlby's views on the effects of early childhood deprivation on character development was John Alford. Alford's own children were at Priory Gate, and he served as a volunteer staff member. Alford, who would later be professor of art at Toronto, was described by Bowlby as a man of many talents who was 
interested in the fields of art, philosophy and psychology. He had been a troubled war veteran and had had analytical therapy from Homer Lane, the American therapist and founder of the school called "The Little Commonwealth" in England ${ }^{37}$ This coeducational school was meant for delinquent adolescents, and Lane was one of the first to use psychoanalytic ideas in the education of such children. ${ }^{38}$ Alford's enthusiastic discussions of Lane's ideas aroused Bowlby's interest in the latter's ideas. While at Priory Gate he read Elsie T. Bazely's Homer Lane and the Little Commonwealth and Lane's own book, Talks to Parents and Teachers. These ideas impressed him so much that fifty years later he would still rate Lane's book among the eleven books that most influenced his thinking. ${ }^{39}$ Lane's claim that deprivation of love in childhood is the source of delinquency and that many disorders can be traced back to inadequate behavior by the child's parents clearly appealed to Bowlby. Alford, then, introduced Bowlby to Lane's influential ideas about the origin of delinquency. In Bowlby's recollection, Alford was an open-minded, modest, and intelligent person with whom he could discuss these issues in ways that were profitable to him. Alford, who was about fourty at the time and thus much older than Bowlby, gradually became Bowlby's guide and adviser. He encouraged Bowlby to complete his medical training in London and to train in psychiatry and psychotherapy. ${ }^{40}$

In summary, the period spent at Bedales and, particularly, the period spent at Priory Gate, were of great importance to Bowlby's intellectual development. Not only did this period provide him with an intimate knowledge of the problems and characters of so-called difficult or maladjusted children, it also provided him with a set of ideas about the origin of these problems. Badley, Jennings White, Faithful, Alford, and Lane were all psychoanalytically oriented and, in one way or the other, all traced back the behavioral problems of the maladjusted children to inadequate parent-child relationships in childhood. Badley and Jennings White emphasized, among other things, the dark side of dominant parents and suggested that improvement would come from providing children with a secure environment and freeing them of the bad influence of their parents, a suggestion that points to their belief in the detrimental effects of such real-life experiences. Lane, Faithful, and Alford also emphasized the importance of good affective parent-child relationships and suggested that it is deprivation of love that leads to pilfering, lying, and other behavioral difficulties. No wonder, then, that Bowlby more than fifty years later remarked that "Apart from a medical background and an interest in psychology, my choice of career had been determined by what I had seen and heard during the six months that I had spent in a school for disturbed children." 41

\section{MEDiCAL AND PSYCHOANALYTICAL TRAINING}

In order to be able to study psychiatry, Bowlby had to finish his medical training. There is little doubt that he considered this a necessary evil: although he found some of the subjects, such as physiology and pathology, quite interesting, he had no intention of practicing as an ordinary doctor. By now his real interests were in psychiatry, and psychoanalysis in particular. ${ }^{42}$ Bowlby decided to study at University College Hospital, rather than at St. Bartholomew's Hospital where his father had studied, because he thought well of the quality of University College Hospital and because he could then study under Bernard Hart. In 1933, at the age of twenty-six, he received his degree in medicine. Interestingly, Bowlby had not been able to resist the temptation to deepen his understanding of psychoanalysis before this date. Already in 1929 he began his psychoanalytic training.

At the time, there were two places where one could sign up for psychoanalytic training, the Tavistock Clinic and the Institute of Psycho-Analysis. Alford had advised Bowlby to sign 
up at the Institute of Psycho-Analysis, the training center for future analysts of the British Psycho-Analytical Society, as in his opinion this institute was somewhat more professional than the "eclectic" Tavistock Clinic, and Bowlby followed his advice. ${ }^{43}$ As he was still quite young - twenty-two at the time - and had not yet finished his medical studies, Bowlby was accepted only provisionally. The greater part of the training of future analysts was devoted to personal or training analysis, and Bowlby was assigned to Joan Riviere, a friend and follower of Melanie Klein and a translator of Freud. Bowlby's lengthy personal analysis with Riviere eventually would lead to tensions, and with hindsight it is easy to understand why it did. At Cambridge, Bowlby had been taught the canons of empirical research, and he found it difficult to accept certain psychoanalytic notions that he believed were based upon no more than dogmatic belief: "As a somewhat arrogant young man with a number of academic friends . . . I was in no mood to accept dogmatic teaching." 44

Bowlby believed that his academic attitude was intensified by endless debates with his friends, the economists Evan Durbin and Henry Phelps Brown. Both were powerful debaters, and "any position I took up I had to justify up to the hilt by argument and evidence. This was an invaluable discipline, I think." Although Durbin (with whom Bowlby would later write a book on the psychoanalytic origins of war) and Phelps Brown were both actively interested in psychoanalysis, they never ceased to put challenging questions to Bowlby ${ }^{45} \mathrm{He}$ remembered that "My analyst was not altogether happy with my critical attitude and complained on one occasion that I would take nothing on trust and was trying to think out everything from scratch, which I was certainly committed to doing." 46

The tensions between Riviere and Bowlby must also be seen against the background of the general intellectual climate in the British Psycho-Analytical Society. Founded by Ernest Jones (1879-1958) in 1919, it soon developed into a place where orthodoxy threatened to take the place of open-minded scientific debate. It was Jones who, together with Edward Glover, made all the relevant decisions (such as the decision who would be eligible as a member of the Society), who tried to prevent dissenting opinions, and who attempted to control the activities of the Society's members. Thus, for example, he forbade psychoanalysts to work at the Tavistock Clinic. ${ }^{47}$

The British Psycho-Analytical Society, then, was not the ideal place for detached and disinterested discussions of conflicting viewpoints, and Riviere was probably not prepared to face the arguments of a self-assured and possibly slightly arrogant young man. But another factor may have been of much more significance. As noted above, Riviere was a friend and follower of Klein, who had become a member of the British Psycho-Analytical Society in 1926, when she moved from Berlin to London. Backed by Jones, Klein quickly attained a leading position in the Society. By 1929 she was already recognized as a training analyst and elected as a member of the Training Committee. By the end of 1934, Klein had given eleven papers or short presentations before the Society that were on the whole received rather well. ${ }^{48}$

Many members of the British Society shared Klein's belief in the importance of "pregenital and innate determinants over and above the influence of external and environmental stress, and their vital role in determining beliefs and perceptions of reality." ${ }^{49}$ In 1932, several years after Bowlby started his training analysis, she published The Psychoanalysis of Children, which was quite influential in the British Society. In this book, she introduced her play technique as a means to analyze very young children. She argued that she did not seek cooperation of the parents of a child, firstly because their reports were likely to be distorted by their own unconscious conflicts, and, secondly, because she attached little significance to the real-life situation. In addition, she laid great emphasis on destructive aggression that she 
held to be innate and a manifestation of the death instinct ${ }^{50}$ These views alone, if fully shared by Riviere, would have been enough to cause some tension between Bowlby and his analyst, since, unlike Klein, he had come to believe in the significance of real-life events in early childhood for later character development, and, in later years, he would seek the active cooperation of the parents of a disturbed child. Nevertheless, despite the obvious tensions between Bowlby and Riviere, he was accepted as a candidate for further training in psychoanalysis in $1933 .{ }^{51}$

\section{SPECIALIZING IN PSYCHIATRY}

In this same year, Bowlby finished his medical studies and began working as a clinical assistant at the Maudsley Hospital. He wished to study adult psychiatry because he needed experience in adult psychiatry in order to be eligible for a Commonwealth Fellowship in child psychiatry, the area of his real interest. Maudsley Hospital was headed by Edward Mapother (1881-1940), London's first professor of psychiatry and, after initial enthusiasm, a stout opponent of psychoanalytic doctrines. ${ }^{52}$ His co-worker Aubrey Lewis, who became Bowlby's supervisor, was equally critical of Freud's ideas. Like many others before and after him, Lewis liked to compare the psychoanalytic movement to a religious sect: "Disciples gathered round the Master; defections, schisms and heresy; scriptures reproduced with Masoretic devotion; and a prolonged ritual preparation of oblates - all of these have their close parallels in the history of sects and cults." However, Lewis seems to have been an open-minded figure who did not impose his own views and Bowlby remembered that on many questions they "agreed to differ." 53

At the Maudsley Hospital, Bowlby carried out research on personality types associated with psychotic and psychoneurotic breakdown. He was fascinated by such questions as "What sort of man was he before he became ill?" and "In what ways, if any, was this patient more unstable or neurotic than others?" Bowlby spent many hours discussing those questions with the patients themselves and with their relatives. In constructing their psychosocial case histories, he became aware of bereavement as a factor in psychosis: "The illness or death of a near relative is an exceedingly common precipitating factor in both psycho-neuroses and functional psychoses." He came to recognize certain characteristic personality types that seemed specially liable to develop a functional mental illness. With the data collected at the Maudsley Hospital, Bowlby developed a classification scheme of mental illnesses and linked the illnesses of many patients to the losses they had experienced. This work was accepted for an MD degree in 1939 and became subsequently published as Personality and Mental Illness: An Essay in Psychiatric Diagnosis. ${ }^{54}$

In 1934, while still working at the Maudsley Hospital, Bowlby was appointed clinical assistant at the Department of Psychological Medicine at University College Hospital. During the next year, he investigated and treated mentally retarded and abnormal children under the supervision of Alfred F. Tredgold. Tredgold, a specialist in mental deficiency, was particularly interested in unmanageable, stubborn, and unresponsive children whose impulses might lead to undisciplined and criminal ways. ${ }^{55}$

During the next two years, 1936 and 1937, Bowlby worked under Bernard Hart. Hart had initially been quite enthusiastic about many of Freud's speculative ideas that he found "no more and no less unthinkable than the mathematical concept $\sqrt{ }-1$." He also had been a member of the short-lived London Psycho-Analytical Society and had published a psychodynamic book on mental disturbances. This book had become the most widely read introductory book and was obligatory reading for psychiatric trainees. ${ }^{56}$ By the time Bowlby 
arrived at the Maudsley Hospital, however, Hart had become more skeptical and he criticized many of the Freudian findings as well as the psychoanalytic methodology. ${ }^{57}$ Under Hart's supervision, Bowlby was in sole charge of a considerable number of cases at the out-patient Department of Mental Cases. Judging by a letter of recommendation which Hart wrote on behalf of Bowlby, he seems to have been pleased with Bowlby's work. ${ }^{58}$ In parallel with the work at the Department of Mental Cases, Bowlby also worked at the Department for the Psychological Disorders in Children under the supervision of William Moodie, with whom he would also work at the London Child Guidance Clinic (see below).

\section{ENTERING THE ACADEMIC FIELD}

From about 1933 it becomes increasingly difficult to disentangle Bowlby's activities, to chart out the influences he underwent, and to understand the development of his thinking. During a period of roughly six years (1933-1939), Bowlby not only worked at the Maudsley Hospital (see above) but also worked for short overlapping periods at various institutes, continued his personal psychoanalytic training, started a training in child analysis, and began carrying out research for a $\mathrm{PhD}$. It is to this last period that we turn first.

Stimulated by his friend Durbin, Bowlby decided to register as a $\mathrm{PhD}$ student at University College London in 1933. He became a PhD student under Sir Cyril Burt (1883-1971) whose work hardly needs discussion..$^{59}$ In practice, at least some of Bowlby's supervision was probably carried out by Susan Isaacs (1885-1948), head of the Department of Child Development at the University of London. Isaacs had been appointed by Burt in a part-time capacity to supervise advanced psychology students and to lecture on child growth at University College. She was a member of the British Psycho-Analytical Society, and in this capacity Bowlby had known her already for several years. ${ }^{60}$ During World War II, Bowlby and Isaacs would work closely together on the issue of the war-time evacuation of young children.

Bowlby's first title for his PhD research was "Interrelation of Sexual and Aggressive Impulses," a title that points to a rather orthodox psychoanalytic theme. One year later, he changed this title into "An Examination of Guilt and Anxiety on the Basis of Case-Studies." In his thesis he planned to discuss several psychoanalytic theories, among them those of Freud and Klein. It is unclear whether Bowlby planned to do empirical research for his thesis. The fact is that he never finished this project and instead submitted his classificatory work on personality for a MD degree (see above). ${ }^{61}$

The work under Burt and Isaacs lasted for about three years and-despite its apparent unproductivity - was important in several respects. Again, of course, Bowlby was working in an intellectual climate that was benevolent to psychoanalytic thinking. But again it was a climate in which psychoanalytic ideas did not go unchallenged and in which they were combined with different ideas and traditions. Burt's eclectic approach combined psychoanalytic insights with empirical research and statistics. In his later career, Bowly would repeatedly claim that he favored a similar approach. Burt's emphasis on the importance of (the mother's providing) a stable home environment and his warning not to remove children unduly from this environment was accepted by Bowlby from his very first papers. ${ }^{62}$

\section{WORKING AS A CLINICIAN}

In November 1934, after his psychoanalytic colleague Dennis Carroll had recommended him, Bowlby was asked to become an honorary member of the staff of the Institute for the 
Scientific Treatment of Delinquency (ISTD).$^{63}$ The ISTD had been founded in 1932 and was headed by Edward Glover, an advocate of the psychoanalytic approach to crime, and Emmanuel Miller, director of the East London Child Guidance Clinic. The chief aim of the ISTD was to provide facilities for examination and, where possible, treatment of cases of antisocial conduct, especially among young people. In accordance with a growing conviction of that time, Glover felt that juvenile crime was the result of mental problems and that the offenders needed treatment rather than punishment. ${ }^{64}$

Besides giving therapy, staff members of the ISTD carried out scientific research into the causes and prevention of crime. As scientific experts, they assisted and advised the judicial and magisterial bench, hospitals, and government departments. Another object of the ISTD was to promote discussion and to educate the opinion of the general public on delinquency by publications. The ISTD flourished, and while Bowlby was still working there, in 1937, an out-patient clinic, called the Psychopath Clinic, was opened. The majority of the cases at the ISTD came from a Magistrate's Court but large numbers were referred by medical practitioners as well. ${ }^{65}$

Bowlby treated cases at the ISTD for a few hours a week. Although the ISTD was largely based on work by psychoanalysts, it was not an exclusively psychoanalytic institution which recruited its members from the British Psycho-Analytical Society. Members of organizations such as the 'eclectic' Tavistock Clinic were involved as well. The idea was that patients were seen by psychiatric social workers, psychologists, and organic physicians and would be provided with individual treatment. The ISTD thus practised the multidisciplinary approach that would be common in the later Child Guidance Clinics. In 1938, after four years and for unknown reasons, Bowlby ended his work at the ISTD. The Scientific Committee of the ISTD expressed its "sincere regret" at Bowlby's decision. ${ }^{66}$

\section{PSYCHOANALYTIC TRAINING CONTINUED}

Meanwhile Bowlby's psychoanalytic training continued. He was still in analysis with Riviere. Since 1933 he had attended psychoanalytic seminars given by, among others, Glover and Ella Sharpe. ${ }^{67}$ And he had begun to analyze his own first cases.

Sharpe and Nina Searle were Bowlby's supervisors in his first two cases. Far from satisfied with Searle ("a prim old maid"), he got along well with Sharpe and claimed to have learned a good deal from her about treating patients as human beings. He was far less positive about his therapeutic success. With hindsight, Bowlby described his first treatment as a definite failure. The woman he analyzed was in a condition of seriously disturbed mourning following the death of her mother with whom she had had a pathogenic relationship, a fact that neither Bowlby nor Searle knew. "I am afraid I helped that patient very little." 68

In 1935 Bowlby came into conflict with the British Psycho-Analytical Society. The problem was that Bowlby had undertaken the private psychoanalytic treatment of patients in addition to those allotted to him by the Training Committee. Moreover, several of these patients (at the Maudsley Hospital) he saw only a few times per week in contrast with the psychoanalytic tradition of giving analysis five times per week. The Training Committee took the view that persons who were not qualified as associate members of the Society should not be allowed to use psychoanalytic techniques when treating patients with psychotherapy. On behalf of the Training Committee, Glover explained to Bowlby that "should he be requested by anyone other than an accredited official of the Training Committee to undertake psychoanalytic treatment, it is his duty to refuse the request." The Training Committee was of the opinion that there was "no guarantee that the use of analytical technique by an unqualified 
analyst on, say, two days a week is not going to have unsatisfactory effects on the patient" and in an additional letter it was once more stated that Bowlby's activities could not be allowed. ${ }^{69}$ The outcome of this conflict is unknown but - as will become clear below - the British Psycho-Analytical Society certainly had the means to ensure the cooperation of its members.

At approximately the same time, Bowlby's problems with his personal analyst, Riviere, had changed for the worse. Apparently, Bowlby found it difficult to discuss certain problems with her because he felt that it might affect his own future. ${ }^{70}$ Phyllis Grosskurth mentions that Bowlby had taken objection to the behavior of Riviere over a certain matter. ${ }^{71}$ The facts are that Bowlby requested another personal analyst from the Society. The Training Committee in the person of Glover replied that in their opinion candidates did not have to remain with their analysts. However, they pointed out to Bowlby that "experience had shown that it is advantageous to the candidate that he should not take action in an important matter of this nature without allowing adequate opportunity for analysis to confirm or reject the decision."72 Melitta Schmideberg recalled that Riviere used every conceivable method of emotional appeal to dissuade Bowlby. Among other things, she told him that "he would wreck his career and that there was the danger of his committing suicide as other analysts were probably unable to analyze his depressive position." Isaacs, in her turn, asked Bowlby to come and see her, expressed her concern to him, and wept over his intention to leave Riviere. In the end Bowlby reluctantly decided to stay with Riviere. ${ }^{73}$

The truce with Riviere and the Society, however, did not last. Just a few months later, at the beginning of 1936, Bowlby applied for the qualification to conduct psychoanalytic treatment of adult cases. His personal analysis had at that point been going on for more than six years, and Bowlby felt that it had been long enough. Unfortunately for Bowlby, the Training Committee did not share his sentiments. They believed that the length of an analysis was no reason for qualification, and Glover stated in the best pharisaic tradition that "The Committee cannot fail to be struck by the type of anxiety concerning urgent and premature qualification." Bowlby's request gave the Committee the impression of an "unanalysed situation", and qualification was consequently out of the question. ${ }^{74}$ It would take Bowlby another one and a half years of analysis before he received his qualification. In the summer of 1937, after over seven years of analysis and four years of seeing patients under supervision, Bowlby again requested qualification. Although Riviere was still not satisfied with his progress, she finally gave in. Ernest Jones, the President of the British Psycho-Analytical Society, congratulated Bowlby on his qualification and heartily added that he had "some good idea of what hard struggle you have been through." 75

As argued above, Bowlby's frictions with Riviere may have been caused partially by their different theoretical approaches. By 1935, Bowlby's views had matured, and he more and more realized that his ideas were incompatible with at least one form of psychoanalysis. This was made abundantly clear in January 1935 when Bowlby was invited to participate in the discussion at the British Psycho-Analytical Society following Klein's paper, "A contribution to the psychogenesis of manic-depressive states." In this paper, Klein attempted to show that the super-ego develops at a much earlier stage than was formulated by Freud. She argued that the child's first relationship with the mother forms the basis of an early infantile super-ego. In her view, the introjection of the mother is not a straightforward internalization of the mother as she really is but rather as she is perceived. Also, during the early stage of life, the infant's sadistic fantasies are projected onto the mother and introjected as hostile objects. Klein thus argued that the infantile super-ego owes its sadistic qualities to the child's 
own fantasy life. The severity of the early super-ego produces guilt and anxiety in the child as he or she realizes that the mother whom he or she hates and wants to destroy is the same as the beloved mother who cares for him or her. This causes children to get into what Klein called a "depressive position." Because the "mother" who lives in the child's inner world is considerably different from the child's real mother, the child's psychic reality was more important to Klein than objective reality. Klein thus viewed development as shaped from the beginning by internalization of our relations with others "understood in terms of love and hate and shifting states of mind . . . to which she said such internalization gives rise." This view was in contrast with the view advanced by Freud who saw development in terms of self-generating oral, anal, and genital stages. Klein implied that the 'infantile depressive position' was even more central than the Oedipus complex and believed that the origins of guilt and anxiety lay much earlier in childhood than Freud had believed. Fortunately, through her therapy she was able to reduce the severity of the early superego by interpreting the child's hostile fantasies. ${ }^{76}$

Klein's paper met with both approval and critique from the members of the British Psycho-Analytical Society. Barbara Low, Schmideberg, and Glover criticized, among other things, Klein's use of fantasy and the early dating of the development of the super-ego. ${ }^{77}$ Bowlby remarked that he had recently seen several depressed patients at the Maudsley Hospital and that these patients had suffered recent bereavements. He therefore suggested that such real-life events as bereavement or loss might cause depression and that they are equally as relevant as, and complementary to, Klein's hostile fantasies for the development of depression. To his surprise, his suggestion was brushed aside by Klein and Riviere who believed such experiences in themselves to be of no importance whatsoever. Indeed, in an earlier paper Riviere had written that "[child] analysis has no concern with anything else: it is not concerned with the real world . . . It is concerned simply and solely with the imaginings of the childish mind." $"$ In the margin of this article Bowlby had noted "Role of environment = zero." ${ }^{\prime 79}$ For a long time, however, Bowlby had believed that his and Klein's conception were entirely compatible: one could believe in both the significance of certain very real events and take account of the child's distorted views of these very same events. "At that time," Bowlby recalled, "I had not realized that my interest in real-life experiences and situations was so alien to the Kleinian outlook." 80

\section{WORKING AT THE LONDON CHILD GUIDANCE CLINIC}

In 1936, while still working at University College Hospital and for the ISTD, Bowlby obtained a half-time fellowship for a year in child psychiatry at the London Child Guidance Clinic in Islington, London. After finishing his fellowship, he was appointed half-time child psychiatrist and worked there until the outbreak of World War II. ${ }^{81} \mathrm{He}$ combined this work with some teaching at Morley College and, after 1937, a training in child psychoanalysis.

The idea of setting up child guidance clinics originated in the USA, where clinics for handling of emotional disorders in children sprang up from 1909 onwards. It was Burt who suggested setting up such clinics in Britain. This led to the formation of the Child Guidance Council of which Burt was the chairman and Mapother one of the members. The Council developed a plan for a clinic that was accepted for funding by the Commonwealth Fund of America. The child guidance clinics were to play the role to mental hygiene that the School Medical Service filled with regard to physical hygiene. ${ }^{82}$ The emphasis was thus on prevention rather than cure. As William Moodie, the director of the London Child Guidance Clinic 
formulated it: "The unstable child of today is the neurotic adult of to-morrow - a disturbing element in the community, unhappy and inefficient in himself and a source of misery to those with whom he associates. To avert this is surely worthwhile and it can be done." 83

Child guidance teams consisted of three specialists: a psychiatrist, a psychiatric social worker, and an educational psychologist. ${ }^{84}$ The London Child Guidance Clinic thus formed a multidisciplinary and eclectic setting aimed at explaining and treating deviant behavior by a detailed study of the child in its environment. It is quite remarkable that the older Bowlby, just like several other psychiatrists who had been working there, claimed to have learned most from his cooperation with the social workers, notably Molly Lowden and Nance Fairbairn. "I learned a hell of a lot from them. I learned far more from those two social workers than I learned from my psychiatric colleagues because I don't think they had a great deal to offer." 85

It was Lowden and Fairbairn who first introduced Bowlby to the notion that unresolved conflicts from the parents' own childhood played a large part in causing and perpetuating the problems of their children. Years later, Bowlby still vividly recalled two examples: "In one a father was deeply concerned about his eight-year-old son's masturbation and in reply to my queries explained how, whenever he caught him with his hand on his genitals, he put him under a cold tap. This led me to ask the father whether he himself had ever had any worry about masturbation, and he launched into a long and pathetic tale of how he had battled with the problem all his life. In another case, a mother's punitive treatment of her three-year-old's jealousy of the new baby was as quickly traced to the problem she had always had with her own jealousy of a younger brother." To solve such problems, Lowden and Fairbairn undertook weekly sessions with the mothers, an approach that was enthusiastically applauded by Bowlby. ${ }^{86}$

Two other children caught Bowlby's attention while he was working at the London Child Guidance Clinic. Both displayed a tendency to steal and play truant. The first one was a small boy of about eight who seemed unaffected by praise or blame. The boy had been in a hospital for nine months between the age of eighteen and twenty-seven months without any visiting. He afterwards had never developed any emotional relationship with his parents. Bowlby felt inclined to attribute the boy's condition to that separation experience. This idea was confirmed when he met another child, a little girl, with a very similar condition and a very similar story. "So, generalizing from a sample of two, I concluded that that [a separation experience] causes this [delinquent behavior]." ${ }^{\prime 87}$ Thus it was in this period that Bowlby once more found evidence for his growing conviction that many of the psychological problems with which he was confronted, both in children and in adults, had their origin in faulty or disrupted relationships between the patient and his or her close relatives. To substantiate this idea, he began to investigate the origins of juvenile delinquency. This research, carried out at the London Child Guidance Clinic, eventually resulted in his articles on fourty-four juvenile thieves. ${ }^{88}$

In 1937 Bowlby started his training in child analysis under the supervision of no less than Melanie Klein herself. He still differed with her about the role of inner and external factors in mental disturbance, but it had now become much easier to express his own viewpoints. The reason was that by now many others in the British Psycho-Analytical Society had started casting doubt on Klein's views. Among them were various Berlin analysts who joined the Society after the Nazis seized power in 1933. On the whole, the Berlin analysts favored the alternative view on child analysis developed by Anna Freud in Vienna. In 1938, when Sigmund Freud, Anna Freud and many colleagues arrived in London and joined the British Psycho-Analytical Society, the theoretical differences between the British adherents of the 
Kleinian view and their Berlin and Viennese opponents became even more apparent. Klein's ideas came under increasing attack, and different factions within the British Psycho-Analytical Society slowly developed. ${ }^{89}$

In his very first child analysis, Bowlby clashed with his supervisor. He treated a small hyperactive and anxious boy and noticed that the boy's mother seemed an extremely anxious, distressed, and unhappy woman. As he related this to Klein, she forbade him to spend time with the mother because "it was just something that wasn't done, mustn't be done." The idea that the boy's behavior could be a reaction to the way his mother treated him-one of the key notions at the London Child Guidance Clinic as we have seen - "seemed to escape her." The notion that internal relationships could reflect external relationships was missing from her thinking, and Bowlby recalled that "it was regarded as almost outside the proper interest of an analyst to give systematic attention to a person's real experiences." After a few months of treatment, the news reached Bowlby that the boy's mother had been taken to a mental hospital. As he reported this to Klein, she only seemed concerned with the untimely interruption of the analysis. ${ }^{90}$ This episode made Bowlby once more aware of his theoretical disagreements with Klein, and one can only speculate how long his training would have taken had it not been interrupted by the outbreak of World War II.

In summarizing, we may conclude that the period spent at the London Child Guidance Clinic and the training in child analysis were instrumental in shaping Bowlby's views. His colleagues at the clinic, notably the social workers Lowden and Fairbairn, strenghtened his belief that real rather than imaginary factors influence the child's mental development and pointed to the role of 'intergenerational' effects. Our previous sections on Bowlby's training suggest that the Child Guidance Clinic was by no means the only factor to stir his interest in observational or empirical data: Adrian's approach, Rivers' influence, and Burt's tutorship seem to culminate in Bowlby's divergence from Klein's emphasis on intrapsychic processes. But the period at the clinic was important for his intellectual development. Bowlby never discarded what he felt to be relevant insights in Klein's work (such as her belief in the infant's very early capacity to form relationships and the emphasis she put on loss, mourning and depression, ${ }^{91}$ ) but the down-to-earth approach of the London Child Guidance Clinic with attention to such factors as school marks, disease, and parental behavior must have had a sobering effect on what other, if any, of the Kleinian views he still held. This was no world of fantasies and sadistic projection. It was the very real world of absent or quarrelling parents, bad school marks, pilfering, and truancy. It was the world Bowlby had first known at Bedales and Priory Gate and to which he had now returned equipped with new knowledge and skills. A bigger contrast than the one that existed between the Child Guidance approach and the treatment favored by Klein was hardly conceivable. The period spent at the London Child Guidance Clinic - he later said that it greatly influenced his view on etiology initially formed in 1928 (i.e., at Priory Gate) - finally allowed Bowlby to formulate his own view on the influence of early environment on the development of mental disturbances. ${ }^{92}$

\section{BOWLBY'S EARLY VIEW ON ETIOLOGY}

Bowlby had been an associate member of the British Psycho-Analytical Society since 1937, a position with no voting rights and no right to attend business meetings. In order to qualify as a full member, candidates had to read a paper to the Society. On the basis of his experiences with children seen at the London Child Guidance Clinic, he decided to present a paper that dealt with "The Influence of Early Environment in the Development of Neurosis and Neurotic Character". Based upon a few minor papers he had published in the years 
before, ${ }^{93}$ the paper emphasized the importance of real-life experiences. As such it was rather revolutionary, and Schmideberg, who apparently was aware of its content and sympathized with Bowlby's ideas, warned Bowlby that his paper would not be well received. ${ }^{94}$

Right at the beginning of his presentation Bowlby declared that he had seen about 150 cases of "difficult" children, that in the huge majority of cases he had interviewed their mothers and that his co-workers, Fairbairn and Lowden, had collected data regarding the child's past and present environment. Although Bowlby admitted that such material is "far less intensive than that obtained in analysis", he stated as his belief that the evidence thus gathered complemented the analytic findings and concluded "that this type of research is of much more value in solving certain analytic problems than is research limited to analytic sessions." "The very meagre attention given to the rôle of environment in analytical literature" Bowlby attributed to the fact that analysts in most cases simply were not in the position to do first hand observations. Bowlby looked forward, however, to the day when the analytic interview would be combined with the investigation of the home environment. ${ }^{95}$

Thus Bowlby's position was clear: traditional analytic interviews were needed-although perhaps not with the traditional frequency - but needed to be supplemented with extensive "extra-analytic" data regarding the child's emotional environment and significant events in the child's life course. Such data were, to be sure, still gathered from an analytic angle. Bowlby explicitly stated that he ignored such aspects of the child's environment as economic conditions, housing conditions, and religious teaching. His main interest was in the emotional atmosphere of the home and the early personal environment of the child.

On the basis of his findings at the London Child Guidance Clinic, Bowlby suggested that factors operational in the early years of the child are most important (as these influence the "whole cast of the character"96) and that they can be distinguished into (a) potentially harmful specific events and (b) the mother's negative emotional attitude. Of these specific events by far the most important in his opinion were the separations between the mother and the child (among which the separation caused by the death of the mother). On the basis of an examination of his files, Bowlby concluded that a "broken mother-child relationship" in the first three years of life often leads to emotionally withdrawn children who do not develop "libidinal ties" with others. Of sixteen cases of emotionally withdrawn children who were prone to stealing, the so-called affectionless thieves, fourteen turned out to have experienced major separations from their mother in the first three years of their life. In thirty cases of other thieves, Bowlby found another five separations, while in fourty-four cases of non-thieves there were only three separations to be found. On the basis of these findings, which he would subsequently greatly elaborate and submit to statistical analysis, Bowlby concluded that a certain clinical syndrome - the affectionless thief - is caused by major separation experiences. He added that in his view the further conclusion that minor breaks as well may have a damaging effect on a child's development seemed to follow.

Bowlby discussed several case histories of children whose neurotic parents had an adverse effect on their emotional development. Mothers who simultaneously love and unconsciously hate their children will tend to have children who show the same ambivalence of feelings, he asserted. The child loves its mother but at the same time its mother's hostile attitude will cause it to experience strong feelings of aggression and frustration. This leads to emotional conflict, repression by the super-ego and feelings of guilt. Bowlby emphasized that such ambivalent and neurotic parents do really and objectively exist ("Much has been written about the introjection of phantastically severe parents, an imaginary severity being itself the product of projection. Less perhaps has been written recently about the introjection of the parents' real characters") and that neurotic symptoms tend to be transmitted from one 
generation to the next unless we take measures to treat both the child and the parents. In fact, he suggested that "ideally both mother and child should be seen at the same time by different workers, and this is a procedure which I habitually attempt." 97

Bowlby concluded that a careful statistical comparison between the environment of neurotic children and that of normal children was required in order to be able to reach definite scientific conclusions. He felt allowed, however, to draw some preliminary conclusions from his findings: (1) mother and child should be separated only in cases of absolute necessity. In such cases (e.g., hospital admission) one should try to arrange for daily visits or replacement of the mother by persons the child knows well and feels comfortable with. Avoidance of prolonged separation should become a tradition "in the same way that regular sleep and orange juice have become nursery traditions"; (2) in the case of neurotic mothers, both mother and child should be treated. "A weekly interview in which their [the mothers'] problems are approached analytically and traced back into their childhood is sometimes remarkably successful"; (3) in analyzing adults we may retrospectively get an impression of the real personalities of the adults' parents during their childhood and of the objective events they experienced, and this knowledge may help us in the treatment. ${ }^{98}$

Although Bowlby's whole presentation was still very much couched in traditional psychoanalytic terms, and although his treatment of the damaging role of mothers' hostile unconscious attitudes was still in Kleinian terms, it is no exaggeration to state that his whole presentation was a slap in the face of Melanie Klein and her followers. His statements that "this type of research is of much more value . . . than is research limited to analytic sessions," that "Less perhaps has been written recently about the introjection of the parents' real characters," and his general emphasis on the causative role of real-life experiences was anathema to the Kleinian group in the British Psycho-Analytical Society. ${ }^{99}$ Moreover, one may surmise that Bowlby's large-scale empirical approach, his comparative approach, and his urge for statistical analysis was somewhat foreign to the average analyst.

Perhaps to his own surprise, however, Bowlby met with less resistance than might be expected. Various people, among them Susan Isaacs, supported him during the discussion following his presentation. And when, approximately one month later, at the business meeting of the Society his name was put forward for election as a full member, he was defended by Ella Sharpe, James Strachey, Edward Glover, and Melitta Schmideberg against an attack by Rickman, Winnicott, and (somewhat less obviously) Riviere, who raised the question whether associates should be elected on the strength of such papers. ${ }^{100}$ Bowlby had won his first battle in the British Psycho-Analytical Society. In the years to come, he would gradually become one of the most prominent members of the group and greatly elaborate and revise his ideas until they grew into what was to be called attachment theory.

\section{CONCLUSIONS}

Traditional accounts of the origins of attachment theory have pictured Bowlby's theoretical conflict with Melanie Klein as the first important stage in his intellectual biography. ${ }^{101}$ In his first major article, Bowlby argued that objective factors in the child's early social environment, notably emotional trauma caused by faulty and disrupted relationships with parents or close relatives, can and often do play an important role in causing maladjustment and delinquency. ${ }^{102}$ This argument was clearly directed in part against Melanie Klein's ideas, which emphasized the power of the child's instincts and fantasy life to the exclusion of reality and experience. The historians of attachment theory have been justified, then, in highlighting this theoretical conflict as it both marks an important event in the de- 
velopment of the attachment paradigm and concerns an important and recurrent theme in psychoanalytic theory.

What was largely left unanalyzed, however, was how exactly Bowlby arrived at the views expressed in the above-mentioned article. In this paper, we have tried to identify the origins of Bowlby's disagreement with Klein by charting out relatively little known periods and events in Bowlby's intellectual development. Using archival materials and private correspondence that has only recently become available, we have examined Bowlby's path toward an independent view on the origins of childhood deviancy and maladjustment. The experience and knowledge gathered during various periods in Bowlby's life - his study at Cambridge, his stay at several progressive schools, his medical, psychoanalytic and psychiatric training, his Ph.D. research under Burt, and his work at various institutes - significantly contributed to the formulation of his viewpoint. Bowlby's position was in no way determined by these influences. He selectively adopted, transformed and rejected the various viewpoints he encountered. But they do constitute the background against which his emerging viewpoints must be interpreted.

We thus hope to have shown that there was a "Bowlby before Bowlby," that is, that the Bowlby who confronted Klein by presenting his own independent point of view was preceded by several other Bowlbys who selectively absorbed and digested the ideas of their time. Bowlby's first major article, in which he argued that objective factors in the child's early social environment may cause the child to develop neurotic symptoms, was as much the beginning of a new paradigm as it was the culmination point of his earlier intellectual history.

\section{NOTES}

This research was made possible by travel grants (NWO-SIR 12-2427; NWO-SIR 12-1708) to the first author from the Netherlands Organization for Scientific Research (NWO). More information on the young Bowlby can be found in Suzan van Dijken, John Bowlby: His Early Life (London: Free Association Books, 1998).

1. John Bowlby, "The Abnormally Aggressive Child," New Era 19 (1938): 230-234; "Jealous and Spiteful Children," Home and School (1939): 83-85; "Substitute Homes," Mother and Child April (1939): 3-7; "Hysteria in Children," in A Survey of Child Psychiatry, Ronald G. Gordon, Ed. (London: Oxford University Press, 1939), pp. 80-94; "The Influence of Early Environment in the Development of Neurosis and Neurotic Character," International Journal of Psychoanalysis 21 (1940): 154-178; Personality and Mental Illness: An Essay in Psychiatric Diagnosis (London: Kegan Paul, Trench, Trubner \& Co., 1940); “The Problem of the Young Child," New Era 21 (1940): 5963.

2. Inge Bretherton, "The Roots and Growing Points of Attachment Theory," in Attachment Across the Life Cycle, Collin M. Parkes, Joan Stevenson-Hinde, \& Peter Marris, Eds. (London: Tavistock/Routledge, 1991), pp. 9-32; "The Origins of Attachment Theory: John Bowlby and Mary Ainsworth," Developmental Psychology 28 (1992): 759-775; Jeremy Holmes, John Bowlby and Attachment Theory (London: Routledge, 1993); pp. 19-23; Robert Karen, Becoming Attached: Unfolding the Mystery of the Infant-Mother Bond and Its Impact on Later Life (New York: Warner Books, 1994); pp. 32-33, 41-47; Nora Newcombe and Jeffrey C. Lemer, "Britain Between the Wars: The Historical Context of Bowlby's Theory of Attachment," Psychiatry 45 (1982): 1-12.

3. Fernando Vidal, Piaget Before Piaget (Cambridge, Mass.: Harvard University Press, 1994).

4. The authors are grateful to Mrs. Ursula Bowlby, Sir Richard Bowlby, Mrs. Marjorie Durbin, Mrs. Juliet Hopkins, Lady Evelyn Phelps Brown, and Dr. Peter Fonagy for the valuable information they willingly provided in interviews with the first author. They also would like to thank the following persons and institutions for their generous help in acquiring the data for this research: Dr. Richard Aldrich, Institute of Education, University of London; Mrs. Anne Archer, librarian at Bedales School; Dr. P. B. Boyden, honorary secretary of The Society for Army Historical Research; Mr. Julian Brown, archives of the Order of Woodcraft Chivalry; Dr. Derek Edgell, Department of Historical and Political Studies of the LSU College of Higher Education, Southampton; Dr. Stephen Greenberg, Reference/collection access librarian, History of Medicine Division, National Library of Medicine, Bethesda, USA; Michael Haggard, Abberley Hall boarding school, Worcester; Dr. John Springhall, Department of History, University of Ulster, Northern Ireland; Dr. R. Thompson, University of Nebraska, Lincoln, USA; Dr. Lesley Hall and Mrs. Jennifer Haynes of the Contemporary Medical Archives Centre of the Wellcome Institute for the History of Medicine, London; Mrs. Margaret Walker, librarian at The Tavistock Joint Library, London; the Archives of the British Psycho- 
Analytical Society, London; Mr. C. Wilkins-Jones, assistant senior librarian, Norfolk County Council Library and Information Service, Norwich; Library of the Society of Friends, London.

5. Dean Rapp, "The Reception of Freud by the British Press: General Interest and Literary Magazines, 19201925," Journal of the History of Behavioral Sciences 24 (1988): 191-201.

6. Edward Glover, "Psychoanalysis in England," in Psychoanalytic Pioneers, Franz Alexander, Samuel Eisenstein, \& Martin Grotjahn, Eds. (New York: Basic Books, 1966), pp. 534-545; Rapp, "The Reception of Freud,” p. 193. Quoted by Samuel Hynes, A War Imagined: The First World War and English Culture (London: The Bodley Head, 1990), p. 366.

7. Christopher N. L. Brooke, A History of the University of Cambridge, 1870-1990 (Cambridge: Cambridge University Press, 1993), 4: 171; Sydney C. Roberts, Introduction to Cambridge: A Brief Guide to the University from Within (Cambridge: Cambridge University Press, 1934), pp. 72-79. John Bowlby, Karl Figlio, and Robert M. Young, "An Interview with John Bowlby on the Origins and Reception of his Work," Free Associations 6 (1986): 36-64. Edwin G. Boring, A History of Experimental Psychology (New York: Appleton-Century-Crofts, 1950), p. 43. Edgar D. Adrian, "The Mental and the Physical Origins of Behaviour," The International Journal of PsychoAnalysis 27 (1946): 1.

8. Cambridge University Reporter (1926/27): pp. 1084-1085. Bowlby in an undated letter to his mother (CMAC: PP/BOW/ACC.613). The code and the ones that follow refer to files in the Contemporary Medical Archives Centre of the Wellcome Institute. These files also contain Bowlby's correspondence with his mother and his correspondence with colleagues such as Edward Glover and Ernest Jones from which we will quote below. Bowlby in a letter to his mother, 28 June [1927] (CMAC: PP/BOW/ACC.613). In this and the following notes, the year of writing is given in square brackets when it was not present in the original letter and has been inferred by the authors.

9. Newcombe and Lerner, "Britain between the Wars," p. 5. Boring, A History, p. 490. Martin Stone, "Shellshock and the Psychologists," in The Anatomy of Madness: Essays in the History of Psychiatry: Institutions and Society, William F. Bynum, Roy Porter, \& Michael Shepherd, Eds. (London: Tavistock Publications, 1985), 2: 242-271. Malcolm Pines, "The Development of the Psychodynamic Movement," in 150 Years of British Psychiatry, 18411991, German E. Berrios and Hugh Freeman, Eds. (London: Gaskell, 1991), pp. 206-231; Rapp, "The Reception of Freud," p. 197. Bowlby in a letter to his mother, 16 June [1927] (CMAC: PP/BOW/ACC.613). U. Bowlby in a letter to the authors, 14 November 1995.

10. U. Bowlby, personal communication, 17 January 1995.

11. Milton J. E. Senn, Interview with Dr. John Bowlby in London, England, 19th October 1977 (Bethesda: National Library of Medicine, 1977). Cambridge University Reporter, (1927/28): p. 955. (1926/27): pp. 211-213. Frederic C. Bartlett, "Frederic Charles Bartlett," in A History of Psychology in Autobiography, Carl Murchison, Ed. (New York: Rusell \& Rusell, 1961), 3: 39-52; Charles S. Myers and F. C. Bartlett (1925), A Text-book of Experimental Psychology with Laboratory Exercises. (Cambridge: Cambridge University Press, 1925). Leslie S. Hearnshaw, A Short History of British Psychology, 1840-1940 (London: Methuen \& Co, 1964), p. 216.

12. U. Bowlby, personal communication, 7 December 1994. John Bowlby, 11 books that most influenced my work: proposed answer to request for the 10 books/papers which have most influenced my thought (CMAC: PP/ BOW/A.1/7; 1979).

13. Boring, A History, pp. 459-495.

14. Richard Bowlby, personal communication, 24 November 1994.

15. See Rosemary Dinnage, “John Bowlby,” New Society (10 May 1979): p. 323.

16. Sol Cohen, "In the Name of the Prevention of Neurosis: The Search for a Psychoanalytic Pedagogy in Europe 1905-1938," in Regulated Children/Liberated Children: Education in Psychohistorical Perspective, Barbara Finkelstein, Ed. (New York: Psychohistory Press, 1979), pp. 184-219.

17. John Adams, Modern Development in Educational Practice (London: University of London Press, 1924), p. 46.

18. Richard S. Peters, Ed., Brett's History of Psychology (London: George Allen \& Unwin, 1953). Richard J. W. Selleck, English Primary Education and the Progressives, 1914-1939 (London: Routledge \& Kegan Paul, 1972).

19. Bedales, School Prospectus (1993), p. 1, quoted in R. D. Hinshelwood, "Psychoanalysis in Britain: Points of Cultural Access, 1893-1918," The International Journal of Psycho-Analysis 76 (1995): 144. John H. Badley, Bedales: A Pioneer School (London: Methuen \& Co, 1923), p. 19/pp. 119-120. Jonathan Gathorne-Hardy, The Old School Tie: The Phenomenon of the English Public School (New York: The Viking Press, 1978), p. 335.

20. J. H. Badley, A Schoolmaster's Testament: Forty Years of Educational Experience (Oxford: Basil Blackwell, 1937), p. 68. J. H. Badley, "Bedales School," in The Modern Schools Handbook, Trevor Blewitt, Ed. (London: Victor Gollancz, 1934), pp. 50-51.

21. Bowlby in a letter to his mother, 30 September [1928] (CMAC: PP/BOW/ACC.613). Bowlby in a letter to his mother, 11 November [1928] (CMAC: PP/BOW/ACC.613). Bowlby in a letter to his mother, 21 October [1928] (CMAC: PP/BOW/ACC.613).

22. Bowlby in a letter to his mother, 22 November [1928] (CMAC: PP/BOW/ACC.613). Bowlby in a letter to his mother, [December 1928] (CMAC: PP/BOW/ACC.613). 
23. Bowlby in a letter to his mother, 22 November [1928] (CMAC: PP/BOW/ACC.613). Jonathan Croall, Neill of Summerhill: The Permanent Rebel (London: Ark Paperbacks, 1984), p. 169.

24. Bowlby in a letter to his mother, 1 December [1928] (CMAC: PP/BOW/ACC.613). Alice Smuts, Interview with Bowlby, 6 June 1977, p. 2 (CMAC: PP/BOW/A.5/2).

25. Derek Edgell, The Order of Woodcraft Chivalry, 1916-1949, as a New Age Alternative to the Boy Scouts (Lewiston, NY: The Edwin Mellen Press, 1992), p. 383.

26. Aubrey T. Westlake, Woodcraft Chivalry Adapted from Seton's "Woodcraft Indians" (London: The Order of Woodcraft Chivalry, 1917), p. 3. Idrisyn O. Evans, Woodcraft and World Service: Studies in Unorthodox Education (London: Noel Douglas, 1930), p. 57. Ernest Westlake, "The Forest School (1): The Principles of Education of the Order of Woodcraft Chivalry," Pine Cone 1 (1923): 15.

27. Margaret A. Westlake, The theory of woodcraft chivalry: A short statement. 'The Woodcraft Way' series no. 2 (London: The Order of Woodcraft Chivalry, 1918), p. 12. Westlake, Woodcraft Chivalry, p. 4.

28. Edgell, The Order of Woodcraft Chivalry, pp. 382, 381.

29. George H. Green, Psychanalysis in the Class-Room (London: University of London Press, 1921); Norman MacMunn, The Child's Path to Freedom (London: G. Bell \& Sons, 1921); Hugh Crichton Miller, The New Psychology and the Teacher (New York: Albert \& Charles Boni, 1927); Dorothy Revel, Cheiron's Cave: The School of the Future. An Educational Synthesis Based on the New Psychology (London: William Heinemann, 1928).

30. Robert Graves and Alan Hodge, The Long Week-End: A Social History of Great Britain, 1918-1939 (London: Faber and Faber, 1940), p. 104. Adams, Modern Development, p. 269; Faithfull's high opinion of psychoanalysis and its practical applicability in the upbringing and education of children was strengthened by regular discussions with Jennings White, the psychiatric adviser of Priory Gate. Jennings White held that children must be emancipated from their mother and that the removal of a neurotic, delinquent, or difficult child from the influence of his parents forms the most potent cure. See Harold D. Jennings White, The Biological Principles of Education. 'The Woodcraft Way' Series no. 14 (Godshill, Salisbury: The Order of Woodcraft Chivalry, 1928), p. 8. Incidentally, this advice is diametrically opposed to what Bowlby himself would later advise in similar cases.

31. See Edgell, The Order of Woodcraft Chivalry, p. 383. Edgell refers to Theodore J. Faithfull, Bisexuality: An Essay on Extraversion and Introversion (London: John Bale, Sons \& Danielsson, 1927).

32. Bowlby in a letter to his mother, [1928] (CMAC: PP/BOW/ACC.613).

33. Interview with Anthony Bowlby, 11 May 1991 (CMAC: PP/BOW/N.1); Bowlby in a letter to his mother, [December 1928] (CMAC: PP/BOW/ACC.613).

34. U. Bowlby, personal communication, 7 December 1994. Senn, Interview, p. 3.

35. Theodore J. Faithful, Psychological Foundations: A Contribution to Everyman's Knowledge of Himself (London: John Bale, Sons \& Danielsson, 1933), p. 201. See also Virginia Hunter, "John Bowlby: An Interview," Psychoanalytic Review 78 (1991): 163. Faithfull, Psychological Foundations, p. 201.

36. Bowlby quoted in Croall, Neill of Summerhill, p. 169. Dinnage, "John Bowlby," p. 323.

37. Senn, Interview, p. 2; J. Bowlby, "The Role of the Psychotherapist's Personal Resources in the Treatment Situation," in John Bowlby (1907-1990): Papers on John Bowlby Based on Those Printed in The British PsychoAnalytic Society Bulletin, vol. 27, no. 11, November 1991 (London: Mansfield House, 1991), p. 11.

38. Hinshelwood, "Psychoanalysis in Britain", pp. 144-145.

39. Bowlby in a letter to his mother, [February 1929]; Elsie T. Bazeley, Homer Lane and the Little Commonwealth (London: New Education Book Club, 1928); Homer Lane, Talks to Parents and Teachers (London: George Allen \& Unwin, 1928). Bowlby, 11 books.

40. John Bowlby, Obituary of John Alford (CMAC: PP/BOW/B.3/19; 1960). Senn, Interview, p. 3.

41. John Bowlby, "Perspective: A Contribution by John Bowlby," Bulletin of the Royal College of Psychiatrists 5 (1981): 2.

42. Bretherton, "The Roots and Growing Points", p. 10; Senn, Interview, p. 3.

43. Senn, Interview, p. 4.

44. Bowlby, "The Role of the Psychotherapist's Personal Resources," p. 11.

45. Senn, Interview, p. 5. Evan F. M. Durbin and John Bowlby, Personal Aggressiveness and War (London: Routledge and Kegan Paul, 1939).

46. Bowlby, "The Role of the Psychotherapist's Personal Resources," p. 11.

47. Jones' attitude led the contemporary magazine New Age to claim that he had "practically founded a Roman Catholic church which has developed so quickly that it already runs parallel to a holy inquisition. He is the interpreter of the law of Freud, literally and harshly" New Age (1 November 1923), quoted in Rapp, "The Reception of Freud," p. 195.

48. Pearl King, "Background and Development of the Freud-Klein Controversies in the British Psycho-Analytical Society," in The Freud-Klein Controversies 1941-1945, Pearl King and Riccardo Steiner, Eds. (London: Tavistock/ Routledge, 1991), pp. 9-36. P. King, "Early Divergences between the Psycho-Analytical Societies in London and 
Vienna," in Freud in Exile: Psychoanalysis and its Vicissitudes, Edward Timms and Naomi Segal, Eds. (New Haven: Yale University Press, 1988), pp. 128.

49. King, "Background and Development", p. 19.

50. Charles Rycroft, Psychoanalysis and Beyond (Chicago: Chicago University Press, 1986), p. 129.

52. Pines, "The Development of the Psychodynamic Movement", pp. 224-225. Hearnshaw, A Short History, p. 286; M. Pines, "A History of Psychodynamic Psychiatry in Britain," in Textbook of Psychotherapy in Psychiatric Practice, Jeremy Holmes, Ed. (Edinburgh: Churchill Livingstone, 1991), pp. 31-55.

53. Michael Shepherd, A Representative Psychiatrist: The Career, Contributions and Legacies of Sir Aubrey Lewis (Cambridge: Cambridge University Press, 1986), p. 12. Bowlby, "Perspective," p. 2.

54. Bowlby, Personality and Mental Illness, p. 146.

55. William R. Merrington, University College Hospital and its Medical School: A History (London: Heinemann, 1976), p. 229.

56. Bernard Hart, "The Subconscious," in Subconscious Phenomena, Hugo Münsterberg, Theodule Ribot, Pierre Janet, Joseph Jastrow, Bernard Hart, and Morton Prince, Eds. (Boston: Richard G. Badger, 1910), p. 131. Bernard Hart, The Psychology of Insanity (Cambridge: Cambridge University Press, 1912). German E. Berrios, "British Psychopathology since the Early 20th Century," in 150 Years of British Psychiatry, Berrios and Freeman, Eds. p. 233; Hearnshaw, A Short History; Pines, "A History," p. 210.

57. Hearnshaw, A Short History, p. 239.

58. To be found in the Wellcome Institute as CMAC: PP/BOW/A.1/1.

59. Smuts, Interview with Bowlby, p. 10. Burt took great interest in the psychological origins of delinquency. See Cyril L. Burt, The Young Delinquent (London: University of London Press, 1925). He believed that "Nearly every tragedy of crime is in its origin a drama of domestic life" (quoted on p. 99 by Adrian Wooldridge, Measuring the Mind: Education and Psychology in England, c. 1860-c. 1990 (Cambridge: Cambridge University Press, 1994) and argued (much as Bowlby would have) that it is frequently parents rather than children who require treatment and that removing children from their home should only be undertaken as a last resort. See L. S. Hearnshaw, Cyril Burt: Psychologist (London: Hodder \& Stoughton, 1979), p. 81, and Wooldridge, Measuring the Mind, p. 100. Burt also took interest in psychoanalysis. He was one of the founding members of the London Psycho-Analytical Society and became subsequently a member of the British Psycho-Analytical Society. He encouraged the teaching of psychoanalytic theory and was a member of the Council of the Tavistock Clinic. See Pines, "The Development," pp. 219220, and H. V. Dicks, Fifty Years of Tavistock Clinic (London: Routledge \& Kegan Paul, 1970).

60. Lydia A. H. Smith, To Understand and to Help: The Life and Work of Susan Isaacs (1885-1948) (London: Associated University Presses, 1985). Dorothy E. M. Gardner, Susan Isaacs (London: Methuen Educational, 1969), p. 76.

61. CMAC: PP/BOW/B.3/39. Not to finish a PhD project was not uncommon at the time, however. Barely four out of ten registered psychology postgraduates completed their degrees successfully. See Hearnshaw, Cyril Burt, p. 136.

62. See, for example, Bowlby, "Substitute Homes".

63. Letter of honorary secretary to John Bowlby, 13 November 1934 (CMAC: PP/BOW/C.2/1).

64. Hearnshaw, A Short History, p. 290. Edward Glover, "The Diagnosis and Treatment of Delinquency," in Mental Abnormality and Crime, Leon Radzinowicz and J. W. C. Turner, Eds. (London: Macmillan and Co., 1944), pp. 269-299. Edward Glover, The Roots of Crime: Selected Papers on Psychoanalysis. (London: Imago, 1960), 2: 79; cf. H. E. Norman, "Delinquency in Children." The New Era in Home and School 19 (1938): 197.

65. Glover, "The Diagnosis and Treatment," p. 270; Institute for the Scientific treatment of Delinquency, Report for the Year Ended 31st December 1936 (London: The Southern Post, 1937), p. 10 (CMAC: PP/BOW/C.2/1).

66. His colleagues included other members of the British Psycho-Analytical Society, such as Karin Stephen, Adrian Stephen, and Melanie Klein's daughter, Melitta Schmideberg. Priory Gate's psychiatric adviser, Jennings White, was there as well, working as a lay therapist. Two other of Bowlby's colleagues deserve mention at this point. One was Michael Fordham, with whom Bowlby would work at the London Child Guidance Clinic several years later. The other was Ronald Hargeaves with whom Bowlby would work during World War II and who would invite Bowlby to write his now famous report on maternal care and mental health for the World Health Organization. See Institute for the Scientific Treatment of Delinquency, Report, p. 4 (CMAC: PP/BOW/C.2/1); John Bowlby, Maternal Care and Mental Health (Geneva: World Health Organization, 1951). Glover, "The Diagnosis and Treatment", p. 280. The Scientific Committee wrote to him that they appreciated "the help that you have so generously given to the institute". See the letter of the Chairman of the Scientific Committee to Bowlby, 12 January 1938 (CMAC: PP/BOW/C.2/1).

67. John Bowlby, Notes on Members of the British Psychoanalytical Society 1935-1945, p. 8 (CMAC: PP/BOW/ G.1/8); See P. King, "Biographical Notes on the Main Participants in the Freud-Klein Controversies in the British Psycho-Analytic Society, 1941-1945," in The Freud-Klein Controversies King and Steiner, Eds. p xxi.

68. Bowlby, Notes on Members, p. 8. Bowlby, “The Role of the Psychotherapist's Personal Resources," p. 12. 
69. Glover in a letter to Bowlby, 9 April 1935 (CMAC: PP/BOW/G.1/1). Glover in a letter to Bowlby, 18 May

1935 (CMAC: PP/BOW/G.1/1).

70. Rough draft of an undated letter from Bowlby to Glover (CMAC: PP/BOW/G.1/1).

71. Phyllis Grosskurth, Melanie Klein: Her World and Her Work (London: Maresfield Library, 1986), p. 294.

72. Glover in a letter to Bowlby, 21 November 1935 (CMAC: PP/BOW/G.1/1).

73. Melitta Schmideberg, "Comment in Extraordinary Business Meeting of the British Psycho-Analytical Society" Minutes, 11 March 1942 (CMAC: PP/BOW/G.1/3). Cf. Grosskurth, Melanie Klein, p. 294.

74. Glover in a letter to Bowlby, 5 February 1936 (CMAC: PP/BOW/G.1/1).

75. Jones in a letter to Bowlby, 3 December 1937 (CMAC: PP/BOW/G.1/1).

76. King, "Early Divergences", p. 129. Melanie Klein, "A Contribution to the Psychogenesis of Manic-Depressive States," in Contributions to Psycho-Analysis, 1921-1945 (London: The Hogarth Press, 1948), pp. 287, 306-307. "From the beginning the ego introjects 'good' and 'bad', for both of which the mother's breast is the prototype-for good objects when the child obtains it, for bad ones when it fails him. But it is because the baby projects its own aggression on to these objects that it feels them to be "bad"'. See Klein, "A Contribution", pp. 282, 306-307, 310. See also Gail Donaldson, "Between Practice and Theory: Melanie Klein, Anna Freud and the Development of Child Analysis," Journal of the History of the Behavioral Sciences 32 (1996): 160-176 especially 166. Janet Sayers, Mothering Psychoanalysis: Helene Deutsch, Karen Horney, Anna Freud, Melanie Klein (London: Penguin Books, 1992), p. 233. "The infantile depressive position is the central position in the child's development. The normal development of the child and its capacity for love would seem to rest largely on how the ego works through this nodal position." See also Sayers, Mothering Psychoanalysis, p. 225.

77. King, "Early Divergences," p. 129.

78. Joan Riviere, "Symposium on Child Analysis," International Journal of Psycho-Analysis 8 (1927): 377.

79. The paper with Bowlby's marginalia is in the possession of Mrs. Juliet Hopkins, who kindly made it available to us.

80. Bowlby, quoted in Grosskurth, Melanie Klein, p. 402.

81. Cf. Winifred M. Burbury, Edna M. Balint, \& Bridget J. Yapp, An Introduction to Child Guidance (London: Macmillan, 1946). Senn, Interview, p. 5.

82. Burbury, Balint, and Yapp, An Introduction, pp. 3-4; C. J. Wardle, "Twentieth-Century Influences on the Development in Britain of Services for Child and Adolescent Psychiatry," British Journal of Psychiatry 159 (1991): 53-68. Hearnshaw, Cyril Burt, p. 97; Gertrude Keir, "Symposium on Psychologists and Psychiatrists in the Child Guidance Service III-A History of Child Guidance," The British Journal of Educational Psychology 22 (1952): 23. Their primary duty was "the ascertainment, study and correction of minor abnormalities, which if left to themselves, may eventually lead up to gross aberrations of conduct, delinquency and crime," Annual Report for the Chief Medical officer of the Board of Education for 1928 (London: HMSO, 1930), p. 26, quoted in Nikolas Rose, The Psychological Complex: Psychology, Politics and Society in England, 1869-1939. (London: Routledge \& Kegan Paul, 1985), p. 165.

83. William Moodie, The London Child Guidance Clinic: A Survey (London: Bradbury, Wilkinson and Company, n.d., presumably 1936).

84. These operated largely independently and then pooled their expertise under the direction of the psychiatrist. Social workers visited the home of the child and talked to the parents. In cases where this seemed necessary, they offered guidance and advice to the parents. The educational psychologist did the routine (e.g., intelligence) testing. The psychiatrist assessed the child's temperament and its attitude towards those with whom he lived. See, for a full description of how it worked, Olive C. Sampson, Child Guidance: Its History, Provenance and Future (British Psychological Society, 1980).

85. A. Smuts, Interview with William Gillespie, 1977, pp. 9/11 (Archives of the Tavistock Joint Library, 1977). Senn, Interview, p. 12.

86. J. Bowlby, "Psychoanalysis as Art and Science," International Review of Psychoanalysis 6 (1979): 5. J. Bowlby, Early Days at the London Child Guidance Clinic and Training Centre (Archives of the Tavistock Joint Library, 1987).

87. A. Smuts, Interview with Dr. John Bowlby on June 6 and July 23, 1977; and additional written material sent by Dr. Bowlby in September and October, 1979, p. 16 (Made available by Dr. Ross Thompson, University of Nebraska, Lincoln, USA).

88. Bowlby, "Perspective", p. 2. J. Bowlby, "Forty-four Juvenile Thieves: Their Characters and Home-Life," International Journal of Psycho-Analysis 25 (1944): 19-53; 107-128; J. Bowlby, Forty-four Juvenile Thieves: Their Characters and Home-Life (London: Baillière, Tindall, \& Cox, 1946).

89. Grosskurth, Melanie Klein; Russell Viner, "Melanie Klein and Anna Freud: The Discourse of the Early Dispute," Journal of the History of the Behavioral Sciences 32 (1996): 4-15.

90. Bowlby, Interview with R. Karen, 14-15 January 1989, quoted in, Karen, Becoming Attached, p. 46. Bowlby, 
“The Role of the Psychotherapist's Personal Resources," p. 12. Bowlby, "Psychoanalysis as Art and Science,” p. 5. Grosskurth, Melanie Klein, p. 402.

91. Cf. Bowlby, "The Role of the Psychotherapist's Personal Resources," p. 105.

92. Bowlby, Figlio, and Young, “An Interview," p. 37.

93. See note 1.

94. Some years later Schmideberg recalled: "I remember that a few days before Dr. Bowlby's paper driving home from Miss Freud's seminar I said to one of the Viennese - it was either Dr. Hoffer or Dr. Bribing — 'Next Friday your [sic] going to get a sidelight on the London Society. You probably cannot appreciate Bowlby's courage for taking the line he is going to take. You will see how he will be attacked and he must be defended"'. See M. Schmideberg, "Comment in Extraordinary Business Meeting of the British Psycho-Analytical Society." Minutes, 13 May 1942 (CMAC: PP/BOW/G.1/3).

95. Bowlby, "The Influence of Early Environment," p. 154.

96. Ibid., p. 157.

97. Ibid., pp. 173, 176.

98. Ibid., pp. 175, 176.

99. Ibid., p. 176.

100. M. Schmideberg, "Comment in Business Meeting."

101. Bretherton, "The Roots and Growing Points," "The Origins of Attachment Theory," Holmes, John Bowlby, pp. 20-21; Karen, Becoming Attached; pp. 40-47; Newcombe and Lerner, "Britain Between the Wars."

102. Bowlby, "The Influence of Early Environment." 